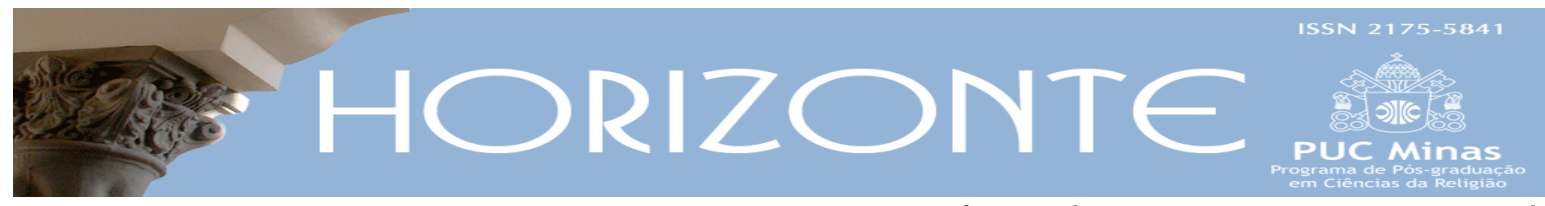

Temática livre - Artigo original

DOI - 10.5752/P.2175-5841.2015v13n39p1630

\title{
Uma Torah anti-hedonista em Fílon de Alexandria
}

\author{
An anti-hedonist Torah in Philo of Alexandria
}

Cesar Motta Rios *

\begin{abstract}
Resumo
A Bíblia hebraica não apresenta o prazer como problema. Não obstante, o envolvimento com a tradição filosófica grega trouxe a intérpretes judeus a possibilidade (quiçá a necessidade) de relacionar seu próprio Livro Sagrado com a questão do prazer. Em Fílon de Alexandria, a Torah se envolve de modo direto em uma oposição ao hedonismo. Neste artigo, observo a forma como essa oposição se realiza no texto de Fílon, e sugiro que se trata de uma oposição de discursos motivada não simplesmente pela resistência ao prazer ou por engajamento no contexto filosófico, mas também pela necessidade de preservação da pertinência do próprio Livro. Antes de abordar a obra do exegeta alexandrino, refiro-me brevemente ao que temos a respeito do prazer na Bíblia hebraica/grega, na Carta de Aristeas e em 4 Macabeus. Esse percurso deverá proporcionar o acompanhamento de um processo de mudança na relação entre os escritores judeus e o tema do prazer. Além disso, evidenciará a especificidade e a sofisticação que se encontra em Fílon.
\end{abstract}

Palavras-chave: Torah; prazer; Fílon de Alexandria; hedonismo.

\begin{abstract}
The Hebrew Bible does not present the pleasure as a problem. Nevertheless, the relationship with Greek philosophical tradition made it possible (or even necessary) to Jewish interpreters to relate their Sacred Book to the question of the pleasure. In Philo of Alexandria the Torah is directly involved in a radical opposition to hedonism. In this article, I observe the way this opposition takes place in Philo's writing, and I suggest that it is an opposition of discourses motivated not only by the resistance to the pleasure itself or by the commitment to philosophical tradition, but also by the necessity of preservation of the pertinence of the Book itself. Before approaching the Alexandrian's works, I refer briefly to what is found on the pleasure in the Hebrew/Greek Bible, in the Letter to Aristeas and in 4 Maccabees. These readings will proportionate the observation of a process of change in Jewish writers' relationship to the theme of pleasure. Moreover, it will make evident the specificity and complexity present in Philo's treatment of this subject.
\end{abstract}

Keywords: Torah; pleasure; Philo of Alexandria; hedonism.

Artigo recebido em: 29 de setembro de 2014 e aprovado em 23 de setembro de 2015.

Trabalho foi realizado com apoio do CNPq, Conselho Nacional de Desenvolvimento Científico e Tecnológico - Brasil

* Doutor na área de Literaturas Clássicas e Medievais pela UFMG. País de Origem: Brasil. E- mail: cesarmottarios@gmail.com

Horizonte, Belo Horizonte, v. 13, n. 39, p. 1630-1657, jul./set. 2015 - ISSN 2175-5841 


\section{Introdução}

O exegeta judeu Fílon de Alexandria (aprox. 10 a.C. - 50 d.C.) trata do prazer como um problema a ser enfrentado. Em suas leituras de várias passagens da Bíblia, mesmo quando o texto interpretado nada diz sobre o tema do prazer, o alexandrino encontra uma maneira (o método alegórico, o mais das vezes) de trazê-lo à exposição.

É surpreendente constatar que no Pentateuco, o corpus mais citado e interpretado por Fílon, o tema do prazer é praticamente inexistente como problema. Se o Pentateuco é acessado pelo exegeta judeu como texto inspirado pelo Deus Criador e caminho para se conhecer a Natureza criada (NIKIPROWETZKY, 1973, p. 324), por que uma questão que não lhe é aparentemente própria recebe tamanha ênfase em sua obra? No sentido de responder essa questão, realizo um breve percurso de leituras, que se inicia na própria Torah e chega ao corpus filoniano, passando pela Bíblia hebraica/grega como um todo, e por dois outros textos selecionados do arquivo judaico que podem trazer alguma contribuição: a Carta de Aristeas e 4 Macabeus.

\section{0 tema do prazer no âmbito da Bíblia hebraica/grega}

O termo hedoné praticamente não é utilizado pelos tradutores do Pentateuco em grego. Figura apenas uma vez em Números 11,8 na descrição do

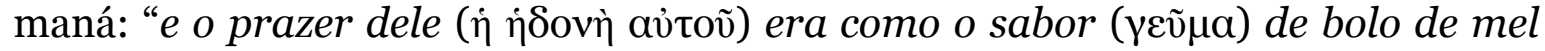
feito com azeite" 1 . Supondo que esse versículo no texto hebraico utilizado pelos tradutores coincide com o Texto Massorético de que dispomos, é razoável pensar que a utilização de i்ovì é uma opção no sentido de evitar a repetição de uma

\footnotetext{
${ }^{1}$ As traduções apresentadas neste artigo são minhas.
} 
mesma palavra, que tem o sentido de "gosto", pois no TM temos: "e era o gosto

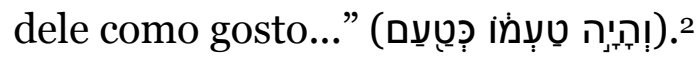

Mesmo se avançarmos para outros textos da Bíblia hebraica, a busca não evidenciará semelhança com a maneira tensa como o prazer é abordado na obra filoniana. Não há textos em que o prazer em si apareça acompanhado de algum tipo de reprimenda.

O Salmo 1 poderia ser tido como uma exceção, uma vez que há ao menos uma crítica indireta, pelo elogio do oposto construído em um paralelismo simples:

Bem-aventurado o homem que não caminha no conselho dos maus, e no caminho dos pecadores não permanece, e no grupo dos debochados não se assenta,

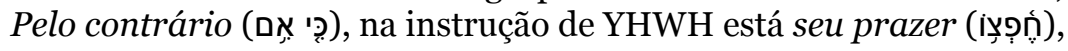

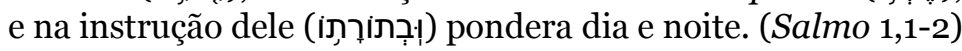

Como se vê, é o termo "prazer", que propus como tradução de ץִ̣, que faz com que os versos anteriores pareçam, por oposição, relacionarem-se com outros possíveis prazeres. Aquele que tem ץִ̣, "prazer”, na instrução/torah de YHWH imediatamente passa a cumprir uma ordem do próprio: nela ponderar dia e noite (Js 1,8)3. A ação é coerente com a fonte proposta para a experiência do prazer, e, portanto oposta a dos homens ordinários. O valor paradigmático do Salmo, que procura influenciar o comportamento do leitor/cantor é evidente (cf. WENHAM, 2012, p.59-6o). Haveria uma proposta ética com relação ao prazer. Não obstante, o

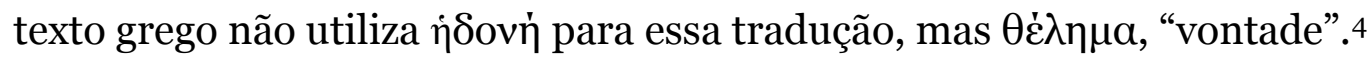

\footnotetext{
${ }^{2}$ Fílon cita parte do versículo em Sacr. 86, mas interrompe a citação justo antes da descrição do sabor com o termo n்ठovń. Em Det.

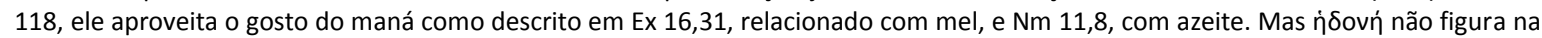
exposição. Ou seja, a única frase em que o termo aparece no Pentateuco não é utilizada por Fílon, que falará do tema a partir de quase todo o Pentateuco. Como contraste, pode-se pensar em Sabedoria de Salomão 16,20, que descreve o maná como alimento "que prevalece ('contém em si', seguindo a Vulgata. No grego, iøxúovta) sobre todo prazer, e se adequa a todo gosto".

${ }^{3}$ Gordon Wenham observa outra relação entre os textos. O primeiro trecho do livro de Josué abre a segunda parte da Tanakh, Neviim, "profetas", enquanto o primeiro salmo abre a terceira parte, Ketuvim, "escritos". Em ambos, a referência à Torah sugere que tudo o que se segue depende da (e aponta para a) Torah (WENHAM, 2012, p. 78-79).

${ }^{4}$ Trata-se de um sentido possível, uma vez que o verbo correlato, ץפ, é inúmeras vezes usado com o sentido de "comprazer-se com algo", indicando justamente a inclinação ou vontade de alguém.
} 
Convém avançar um pouco. Trechos do Qohelet, chamado Eclesiastes na tradição cristã, podem surpreender por possibilitarem leituras que vão diretamente contra uma resistência radical ao prazer. Diz o autor que há tempo

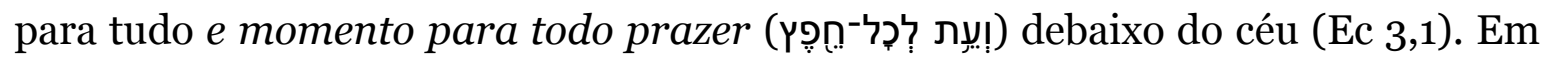
outro passo, refere-se à negatividade dos dias da velhice, convidando o leitor a

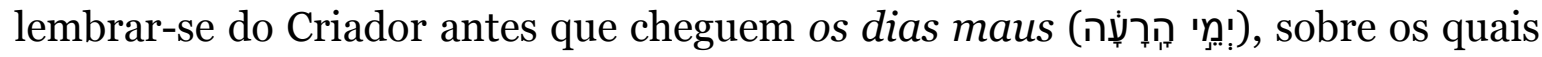

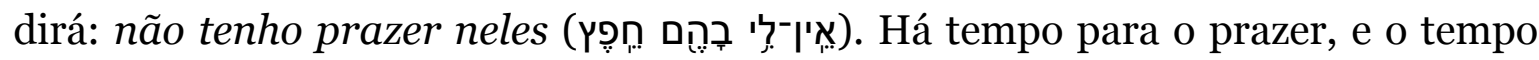
desprovido de prazer é tempo ruim. Contudo, como no caso do salmo citado, também nesses trechos os tradutores evitaram o termo $\dot{\eta} \delta o v \dot{\eta}$, optando por $\theta \dot{\varepsilon} \lambda \eta \mu \alpha$ (Ec 12,1) е $\pi \rho \tilde{\alpha} \gamma \mu \alpha($ Ec. 3,1)5.

É curioso, então, constatar que em certo passo do livro de Provérbios acontece o contrário. Pv 17,1, que não se refere ao prazer em sua versão em hebraico o faz no texto grego:

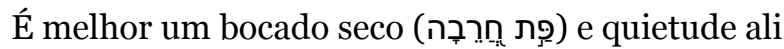
que uma casa cheia de animais sacrificados e contenda.

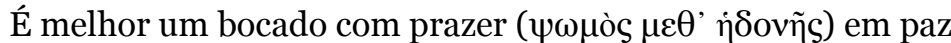
que a casa cheia de muitos bens e sacrifícios injustos com contenda.

Considerando a ausência de um termo correspondente na versão grega para

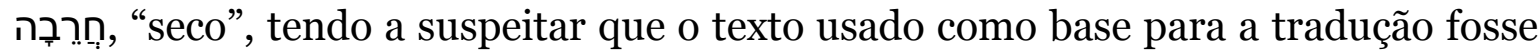
diferente do nosso Texto Massorético nesse verso. É possível supor que, no texto de origem utilizado pelos tradutores, houvesse alguma expressão que os levasse a

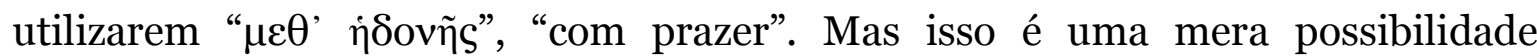
improvada e tida como improvável. É possível, também, que os tradutores tenham querido, com meth'hedonés, enfatizar a expressão "em paz”, e que, para não alongar o verso além da conta, tenham suprimido o adjetivo que acompanharia psomòs, como forma de compensação. Seja qual for o motivo subjacente à escolha

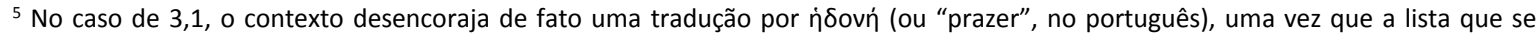
segue nos versos seguintes inclui coisas agradáveis e desagradáveis.
} 
tradutória, o fato é que há variação de sentido. No TM um pedaço de comida seco com paz é melhor que abundância com contenda, o que faz com que o prazer da comida $^{6}$ seja considerado secundário na definição da melhor situação. $\mathrm{O}$ que tem precedência é a paz em oposição ao conflito. Como o texto grego apresenta um bocado com prazer, a oposição não se constrói do mesmo modo. Não é, como no TM, a opção entre o prazer e o desprazer que se opõe a outra que se mostra mais relevante, entre a tranquilidade e o conflito. Pelo contrário, afirma-se a possibilidade de prazer na simplicidade em situação de paz e, do outro lado, acusase a possibilidade de inadequação em uma casa cheia em que há injustiça, o que se reflete na situação de contenda. De certa forma, ambas as versões tratam do prazer, uma explicitamente, outra implicitamente. Cada uma localiza o prazer de determinada forma. O TM parece, nesse verso, reduzir seu valor. A tradução grega reverte a tendência do senso comum e institui o prazer na simplicidade justa, que será apontada como melhor, mas não por causa do prazer em si.

Excetuando-se o caso peculiar desse provérbio, que em ambas as versões podem suscitar uma reflexão sobre o tema, pode-se dizer que a Bíblia hebraica não é resistente ao prazer. Em certos trechos, o TM parece até reconhecer seu lugar de importância. Não obstante, é preciso lembrar que Fílon não acessa o texto em hebraico, mas somente a tradução grega ${ }^{7}$, que, ao que parece, em muitos casos não dá lugar ao (possível) sentido relacionado ao prazer em diversos trechos. Assim, o problema que afirmações como as do Eclesiastes (na versão do TM) poderiam suscitar não é sequer percebido por ele (em sua leitura da Bíblia grega).

\section{Carta de Aristeas: tradutores da Torah, leitores de Aristóteles}

A Carta de Aristeas $^{8}$ narra uma famosa versão sobre a feitura da Septuaginta. Aristeas, o personagem-narrador, participa de uma embaixada

\footnotetext{
${ }^{6}$ Lembro que a noção de comida agradável e prazerosa, na Bíblia hebraica, inclui coisas gordurosas (cf. Is 25,6$)$.

${ }^{7}$ Como a maioria absoluta dos filonistas atualmente, entendo que Fílon não lia o texto hebraico. Ainda assim, reconheço que essa posição, bem defendida e embasada, não pode ser dada como absolutamente definitiva.

${ }^{8} \mathrm{O}$ texto parece ser de aproximadamente 130 a.C.. Para uma discussão detalhada a respeito, cf. HADAS, 2007.
} 
enviada a Jerusalém com o objetivo de buscar tradutores israelitas que possam prover a biblioteca de Alexandria com uma tradução da Torah. Ao descrever o país dos judeus9, o narrador afirma que há ali muitas cidades populosas e prósperas, mas que seus habitantes tratam com negligência o campo, pois todos se inclinam a se comprazerem (i $\lambda \alpha \rho o \tilde{\sigma} \theta \alpha \mathrm{l}$ ) e todos os seres humanos são propensos

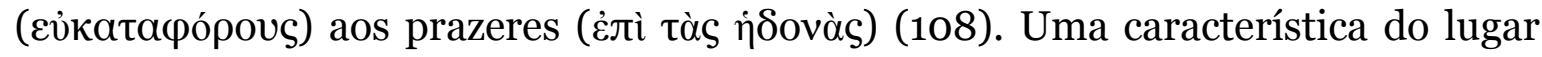
visitado é explicada por uma afirmação que se pretende válida para todos os humanos, e que aparecerá novamente no texto.

Estando os tradutores em Alexandria, Ptolomeu lhes faz perguntas e averigua a sabedoria em cada resposta. Em três desses pequenos diálogos, figura o tema do prazer.

Em 221, ele pergunta a um dos homens qual a mais excelente forma de governo. A resposta vem nos seguintes termos:

O governar-se a si mesmo e não ser arrastado para baixo pelos impulsos (ópuaĩs). Porque todos os seres humanos têm, com relação ao pensamento, uma tendência natural para algo. Para os muitos, por um lado, é normal que se inclinem para os alimentos, as bebidas e os prazeres

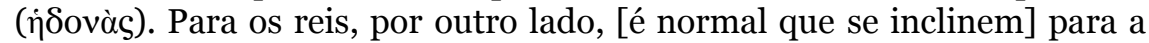
aquisição de território, com vistas à grandeza da glória. Contudo, em tudo é bom ter uma medida ( $\mu \varepsilon \tau \rho$ lótns). Aquilo que Deus dá, tomando-o, segura-o. Mas não desejes o inalcançável. (222-223).

De início, parece que o tradutor desvia o assunto do âmbito político ao individual, mas logo deixa claro que os dois estão conectados. O rei não pode agir como os muitos, devido a seu lugar especial. Ele busca o interesse do país e não o

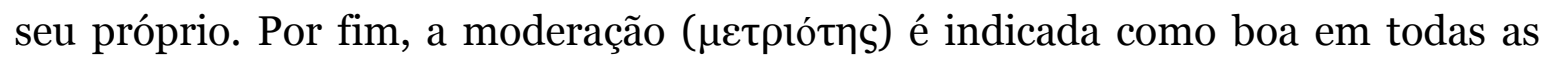
situações. Parece que há uma continuidade entre a ética do indivíduo e a política do estado, assim como medida, moderação e o meio-termo são importantes na Política e na Ética a Nicômaco (E.N.) de Aristóteles.

\footnotetext{
${ }^{9}$ A descrição parece construída a partir daquela da cidade ideal na Política (VII 11) de Aristóteles (HONIGMAN, 2004).
} 
Adiante, o rei questiona a outro como poderia não se entregar aos prazeres (i்ovàs) sendo tão poderoso (245). A resposta aponta a necessidade de que as muitas responsabilidades de um rei e seu dever de fazer o bem aos cidadãos constituam o único alvo de sua atenção.

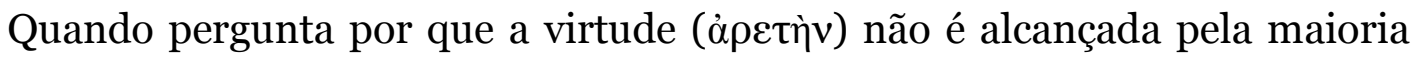
das pessoas, a resposta é a seguinte:

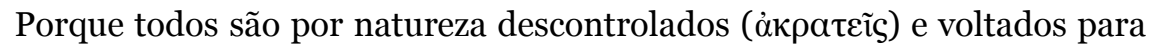
os prazeres, por causa dos quais brotam a injustiça e a inundação do excesso. Mas o hábito da virtude é vedado aos que seguem o domínio do

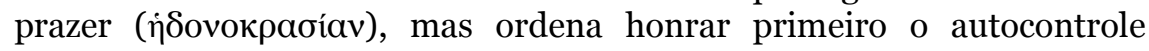

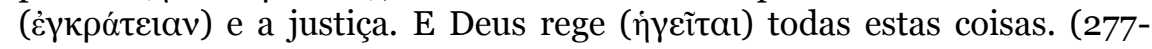
278).

O rei do Egito helenístico de modo verossímil pensa como um grego, pergunta como um grego, e aprova essas respostas dadas pelos tradutores judeus por serem respostas que um "grego" poderia dar. Não afirmo que isso seja menos verossímil, já que os tradutores escolhidos por Eleazar não somente haviam adquirido maturidade com relação às letras judaicas, "mas também na preparação com respeito às [letras] gregas haviam cuidado não como de algo secundário" (121). Apenas sugiro atentar para o fato de que essas respostas dadas pelos tradutores da Torah parecem intelectualmente mais assemelhadas às concepções encontradas na obra de Aristóteles do que ao conteúdo do texto por eles traduzido. ${ }^{10}$ Não obstante, a última frase da resposta há pouco citada faz lembrar a peculiaridade do enunciador. Ele encontra para seu Deus um lugar na dinâmica da resistência ao prazer. E é lugar de comando. Não há, contudo, explicação ou desenvolvimento dessa noção.

\footnotetext{
${ }^{10}$ A questão relativa à privação da maioria com relação à virtude, proposta pelo Ptolomeu, recebe uma resposta semelhante ao

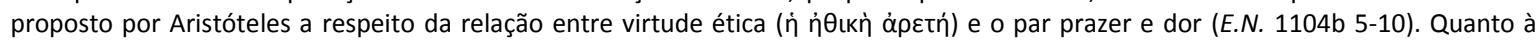
reiterada percepção de que os homens em geral se voltam ao prazer, há muita semelhança com E.N. 1095b 10-15. A influência do pensamento peripatético não é inesperada. A própria metodologia da tradução da Torah como exposta na narrativa se harmoniza mais com a escola aristotélica, implicada nas atividades do Museu de Alexandria, do que com a tradição judaica (HONIGMAN, 2007, p. 141).
} 


\section{Macabeus: a Torah se une ao raciocínio}

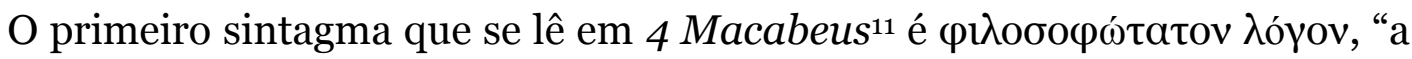
mais filosófica proposição”, que o autor anuncia estar por apresentar. Mas no tratamento do tema do prazer e das paixões, diferente do que se viu em Aristeas, o texto traz a Torah para a reflexão de modo mais articulado.

O autor defende como viável o controle sobre as paixões exercido pelo raciocínio (e só por ele). Mas não se trata do raciocínio simplesmente, mas do

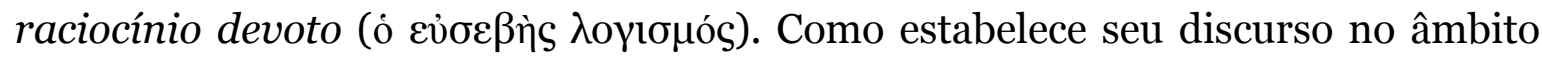
da tradição filosófica grega, o autor propõe-se inicialmente a elucidar o que é ( $\tau i ́$

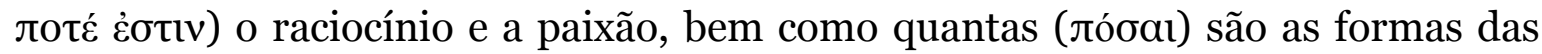
paixões e se ( $\varepsilon i$ ) o raciocínio governa sobre todas elas.

A definição do raciocínio é esclarecedora:

Por um lado, o raciocínio ( $\lambda$ oүı $\sigma \mu \mathrm{s}$ ) é, então, a mente junto com a reta razão (voũs $\mu \varepsilon \tau \grave{\alpha}$ ò $\rho$ oov $\lambda$ ópov), que estima em primeiro lugar a vida de sabedoria. A sabedoria, então, é o conhecimento das coisas divinas e

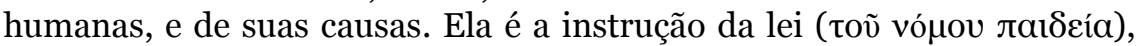
por meio da qual aprendemos as coisas divinas de modo venerável e as humanas de modo conveniente. $\left(1,15^{-17}\right)$.

$\mathrm{O}$ autor encontra um lugar para a lei (vó $\mu \mathrm{o})^{12}$, que certamente seria entendida pelo leitor judeu como se referindo à Torah. O conhecimento das coisas divinas e humanas, bem como de suas causas, que constitui a sabedoria, é a educação da Torah. Talvez essa afirmação seja suficiente para compreender o que o autor entende por raciocínio devoto. Diferente de seus pares helênicos, ele tem

\footnotetext{
${ }^{11} \mathrm{O}$ texto pode provir de algum período entre o final de I a.C. e meados de I d.C. (cf. DESILVA, 1998, p. 14-18), podendo ser anterior, contemporâneo ou até mesmo um pouco posterior à produção do alexandrino.

${ }^{12}$ A Torah não é simplesmente "lei", mas judeus com sólida formação se referiram a ela como vó $\mu$ oఢ, "lei", não necessariamente traduzindo mal, mas expandindo o sentido do termo grego.
} 
um referencial escrito revestido de autoridade divina como fundamento para o conhecimento. ${ }^{13}$

A sabedoria (que provém do ensino da Torah) tem várias formas que se

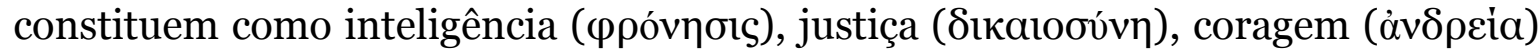
e moderação ( $\sigma \omega \varphi \rho o \sigma u ́ v \eta)$. A mais importante ou comandante é a inteligência ( $\varphi \rho o ́ v \eta \sigma \varsigma)$, e é a partir dela que o raciocínio controla as paixões. Já as naturezas mais abrangentes das paixões se constituem de prazer (†்oví) e aflição (лóvos), que estão ligados por natureza não só ao corpo mas também à alma $(1,20)$. Há

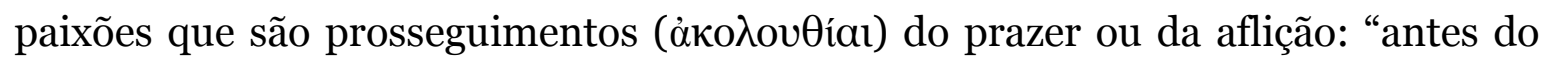
prazer há o desejo, enquanto depois do prazer está o gozo; antes da aflição (лóvos) há o medo, enquanto depois está a dor $(\lambda \hat{\jmath} \eta)$ ” $(1,22)$. Há também paixão que tem em conjunto prazer e aflição, como a ira ( $\theta u \mu o ̀ s)(1,24)$. O prazer recebe ainda maior destaque, uma vez que nele se fundamenta a disposição maliciosa

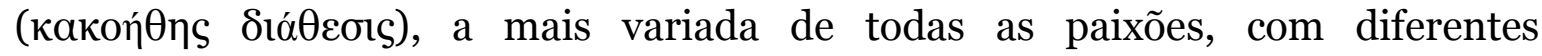
realizações tanto no corpo quanto na alma (1,25-27).

O vocabulário e a reflexão do autor são claramente condizentes com a tradição filosófica grega. Muito do que diz poderia ser considerado próprio do

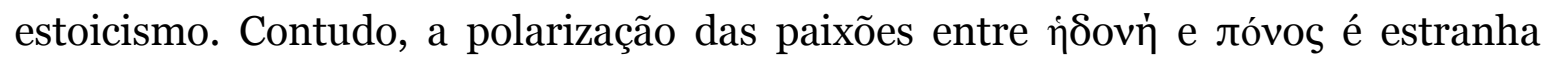
nesse contexto, tanto porque os estoicos as dividem em quatro, quanto porque o

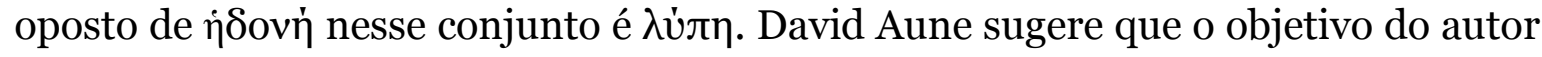
seria preparar o leitor para a parte seguinte do texto, na qual exalta a superação das paixões por parte de judeus que enfrentaram aflições ( $\pi$ óvoı) e abriram mão do prazer (†்ovì) por sua submissão à Torah (AUNE, 1994, p. 135). É preciso

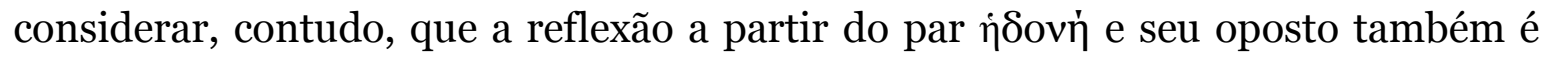
comum na tradição grega. ${ }^{14}$

\footnotetext{
${ }^{13}$ DeSilva observa que essa noção a respeito da origem da sabedoria tem antecedentes claros na tradição sapiencial hebraica, como em Pv 9,10 (sobretudo na versão grega) e Sir. 1,26 (DESILVA, 1998, p. 56).

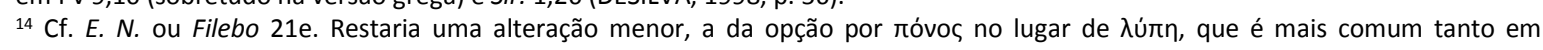
Aristóteles quanto em Platão.
} 
A seguinte ilustração também sugere distanciamento com relação ao pensamento estoico tradicional: Prazer e aflição são como duas plantas nascidas do corpo e da alma, as quais têm muitos brotos. E é ocupando-se diligentemente desses brotos que o agricultor-raciocínio procura amenizar ( $\dot{\xi} \xi \eta \mu \varepsilon \rho o \tilde{)}$ o bosque das paixões e costumes $(1,28-29)$. O raciocínio não extirpa as paixões. Prazer e dor continuam inevitavelmente presentes, mas sob domínio $(3,5)$.

Em certo momento, o raciocínio é novamente relacionado com a Torah. Ao nos voltarmos contra os alimentos proibidos (o autor não define quem seríamos "nós” ou que proibição seria essa, mas o conteúdo já nos assegura que se trata da Torah), repudiamos seus prazeres, porque o raciocínio é capaz de controlar

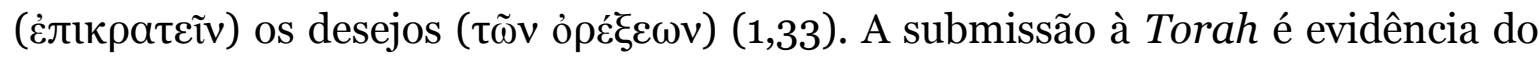
domínio do raciocínio. É de fato nesse sentido que o autor utiliza a expressão

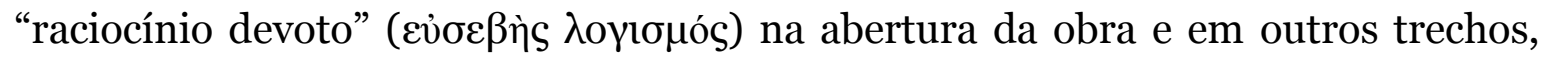
mesmo quando não repete, mas apenas subentende o adjetivo.

Ademais, é importante mencionar que essa associação entre raciocínio e Lei não seria eventual, mas sim definida na própria origem do ser humano:

Porque no tempo em que Deus produziu o ser humano, plantou em redor

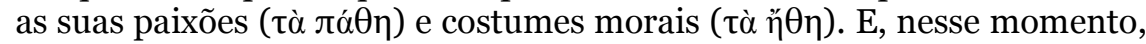

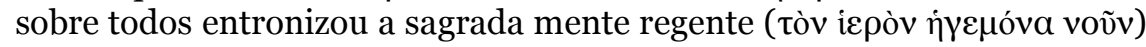

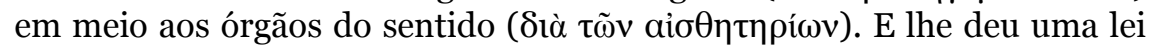
(vónov). Organizando sua vida conforme essa, reinará um reino

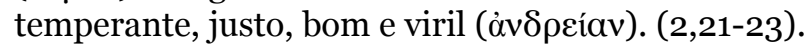

Viver de acordo com a Lei, por conseguinte, é viver de acordo com a constituição original do ser humano. Mas a relação com o texto canônico não fica clara. Em princípio, parece que 4 Macabeus somente aproveita um evento narrado no Gênesis, a criação o ser humano, para aí introduzir a noção da mente regente em relação com a Lei, que lhe será importante, sem estabelecer uma intervenção hermenêutica no texto sagrado. Não obstante, a escolha do termo botânico para se referir à inserção das paixões e costumes morais pode ser rastro de uma 
interpretação alegórica do Éden, não explicitada, mas aproveitada na exposição.

No decorrer do escrito, narrativas da Bíblia hebraica e também da literatura judaica subsequente são evocadas no sentido de ilustrar a resistência às paixões por meio da submissão à Lei, com destaque para o martírio de Eleazar e da mãe e dos sete filhos mártires, que estão registrados também em 2 Macabeus 6,18 a $7,42 . .^{15}$

4 Macabeus se insere na tradição filosófica grega. Mas a inserção da Torah na dinâmica do controle das paixões com sua colocação junto do raciocínio é dado novo. É novo com relação à própria tradição filosófica, obviamente, e é novo em comparação com a Carta de Aristeas.

\section{Fílon e a Torah anti-hedonista: oposição de discursos}

Muito do que se encontra em 4 Macabeus é coerente com a proposta de Fílon, e até mesmo recorrente em sua obra. Não obstante, a disposição do alexandrino para identificar no interior da própria Torah algo que vem de sua formação grega faz com que o Livro Sagrado se torne especialmente envolvido na reflexão sobre e contra o prazer, como fonte das proposições do exegeta. A Torah não fornecerá meros exemplos, mas falará ela mesma sobre e contra o prazer. $\mathrm{O}$ procedimento que pode estar implícito em alguns trechos de 4 Macabeus, em Fílon estará explícito.

Narrativas ou mandamentos que, literalmente, nada dizem sobre o prazer passam a ser estritamente sobre ele. Na interpretação alegórica de Fílon, o prazer recebe tamanho destaque que está presente já no Éden, representado alegoricamente pela serpente, junto com Adão (interpretado como a mente) e Eva

\footnotetext{
${ }^{15}$ DeSilva afirma: "Diferente de Fílon, o autor de 4 Macabeus não usa nenhum exemplo de fora da história sagrada de Israel" (DESILVA, 1998 , p. 59). Contudo, em Fílon, os exemplos não-bíblicos se concentram em Sobre o fato de que todo homem bom é livre, tratado não exegético muito diferente dos demais em diversos aspectos.
} 
(a percepção sensorial), ainda que o texto canônico nada sugira a respeito do prazer na narrativa em si. ${ }^{16}$

Algo semelhante pode acontecer na interpretação do conteúdo legislativo da Torah. Fílon abre o tratado Sobre as Leis Especiais com uma exposição da lei que, segundo ele, causava riso em muitos não-judeus: a circuncisão (Spec. 1.2). Depois de arrolar explicações ouvidas de outros homens dedicados à interpretação da Lei de Moisés (1.4-8), acrescenta que ele mesmo considera a circuncisão como símbolo

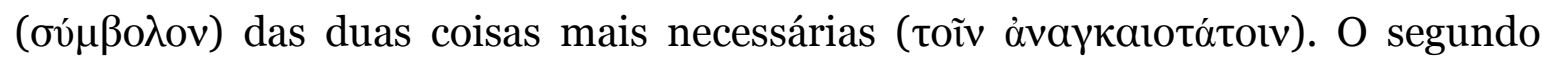
significado simbólico que Fílon apresenta é o "do conhecer a si mesmo e do extirpar da alma uma grave doença, a presunção" (1.10). Já o primeiro significado, apresento-o com sua explicação:

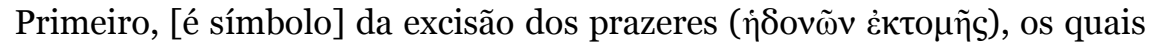
encantam o pensamento (Sióvolav). Pois, visto que dentre as atrações que há nos prazeres a que leva o primeiro prêmio é a relação sexual de um homem com uma mulher, pareceu adequado aos legisladores mutilar a extremidade do órgão que serve a tais relações, indicando

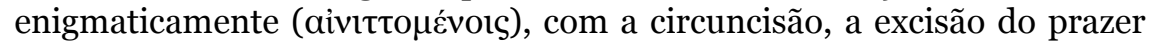

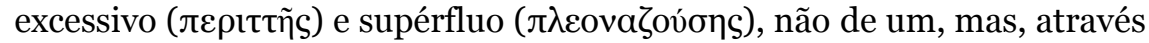

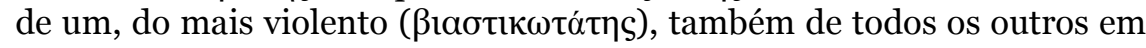
conjunto. (Spec. 1.9).

Como se vê, a circuncisão indica enigmaticamente a excisão de todo prazer excessivo e supérfluo. Esse significado ético só é acessado por meio de uma interpretação simbólica, porque a prática da circuncisão não acompanha qualquer reflexão sobre o prazer nas narrativas da Torah. A questão que propus na introdução pode ser, agora, assim formulada: Por que Fílon encontra dois significados simbólicos consonantes com o pensamento grego, um relacionado ao autoconhecimento e outro relacionado com a moderação para com os prazeres, nessa prática ritual dos judeus? Por que erguer essa lei especial contra o prazer se

\footnotetext{
${ }^{16}$ Cf. Cher. 58ss; Opif. 156ss ; Leg. 2.73ss (há variação na extensão e forma de exposição, mas os significados são mantidos). Embora no meio cristão o relato do Éden tenha se relacionado comumente ao prazer, pela ideia de que o pecado cometido seria o ato sexual, na tradição judaica era normal entender que Adão e Eva mantinham relações sexuais habitando no Éden, sem que isso fosse motivo de culpa (cf. ANDERSON, 1992).
} 
ela nada diz sobre isso em princípio? Há um percurso a cumprir antes de ensaiar uma resposta.

A associação do prazer com a circuncisão não é um procedimento isolado. Fílon faz algo semelhante ao tratar da proibição do consumo da carne suína, mas sem recorrer à alegorese ou recurso semelhante. Em Spec. 4.101, afirma que a

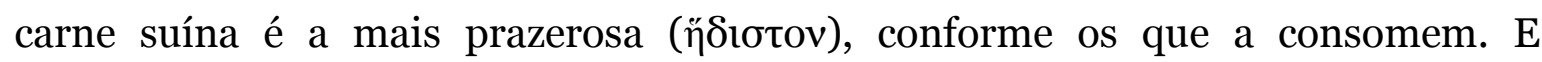
justamente por isso é proibida. O legislador dos hebreus, com vistas ao

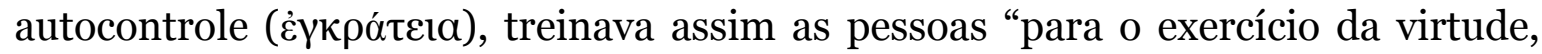
por meio da simplicidade e contentamento”.

A restrição da carne de porco não é explicada a partir de alguma característica negativa do animal. Os não-judeus estranhavam a ausência dessa iguaria no cardápio dos judeus, e Fílon não nega que haja motivo para tal estranhamento. ${ }^{17}$ Pelo contrário, utiliza-se do sabor agradável da carne suína, para explicar sua proibição e exaltar Moisés como dotado de especial capacidade para conduzir seus seguidores ao autocontrole e ao exercício da virtude. A lei que não fazia sentido do ponto de vista da cultura greco-romana em geral, agora passa a se justificar por meio de um valor compartilhado por muitos de seus representantes (claro, muitos dentre intelectuais). ${ }^{18}$

Fílon entende que as leis alimentares estão subordinadas ao décimo mandamento, que ele cita parcialmente. Em vez de dizer "não desejarás a mulher

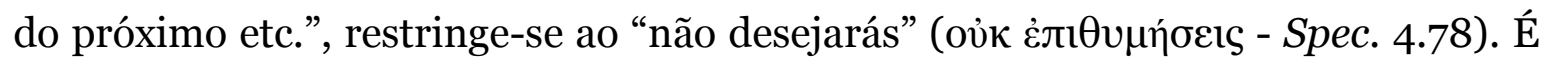
esclarecedor, então, considerar o projeto de Fílon para essa exposição mais ampla:

\footnotetext{
${ }^{17}$ Abster-se de uma carne indesejável não seria estranho. Em Legat. 362, Calígula pergunta aos embaixadores da comunidade judaica alexandrina sobre a restrição ao consumo dos suínos. De modo conciliatório, respondem que cada povo tem seus costumes, e que alguns, por exemplo, não comiam carne de carneiros. Em tom de deboche, o imperador diz que não a comem por não ser gostosa

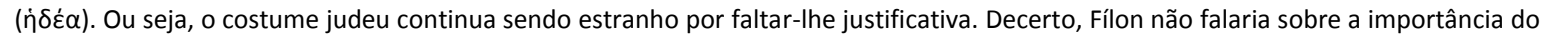
autocontrole a Calígula.

${ }^{18} \mathrm{O}$ fato de que isso não dista do escopo do exegeta fica claro no prosseguimento, pois compara Moisés com outros legisladores,

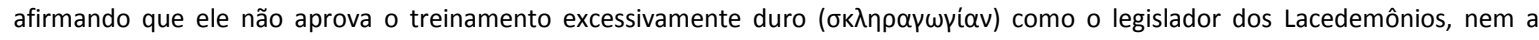
delicadeza do legislador dos Jônios e Sibaritas, mas se coloca como no meio do caminho ( $\mu \varepsilon \dot{\sigma} \eta$ v átparòv). A Lei mosaica não só faz sentido, como é mais adequada que as demais. Fílon é um negociador, que escolhe o argumento a mencionar ou silenciar conforme o contexto. Não se deve supor pelo o fato de ele comparar a Lei mosaica com outras leis comuns que a considere também comum. Ele entende que a Lei é dada por Deus, que criou todas as coisas. Por coerência, então, é necessário que essa Lei seja plenamente concorde com a Lei Natural. Nesse ponto específico, ele se afasta dos estoicos (MARTENS, 2003, p. 96-98; cf. NAJMAN, 2003).
} 
A exposição de Fílon como um todo pode ser sintetizada em termos destes três conceitos: (1) o décimo mandamento proíbe a غ̇ंı $\theta u \mu i$ a apaixonada, (2) a obediência à proibição agrega ao exercício da

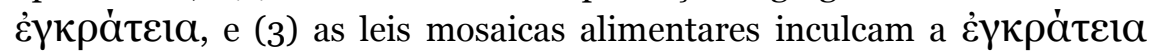

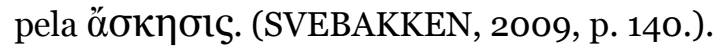

Svebakken percebe que esses conceitos, tal como Fílon os relaciona, são compartilhados pelo Médio-Platonismo de seu tempo. Conclui que o alexandrino trabalha com uma agenda expositiva clara, que inclui um esforço para correlacionar o décimo mandamento com o melhor da filosofia contemporânea (SVEBAKKEN, 2009, p. 141).

De fato, Fílon traz claramente a reflexão grega sobre o prazer de encontro à Torah e vice-versa, como o autor de 4 Macabeus. Além das palavras escolhidas, imagens e argumentos também são indícios de que se relaciona, se não diretamente com os textos mais antigos do debate acerca do prazer, ao menos com uma tradição que detém, lê e discute esses textos. Contudo, o alexandrino não tem uma referência exclusiva, e como não tem o costume de citar nominalmente suas fontes, por vezes, é difícil identificar com precisão qual ele está utilizando em certas passagens.

Em Sobre os Sonhos, por exemplo, ao interpretar o sonho do padeiro do Faraó, que se vê carregando três cestos com pães (Gn 40,16-17), Fílon afirma que a visão se refere à tripartição do tempo, uma vez que "os seguidores do prazer dizem que ele se compõe a partir da memória das coisas agradáveis que se foram, da fruição das coisas que estão presentes, e da esperança das coisas que estão por vir" (Somn. 2.209). Alain Le Boulluec observa que se pode aproximar essa passagem a um pensamento de Epicuro transmitido por Cícero ${ }^{19}$ (BOULLUEC, 1998, p. 142). Não obstante, a percepção de que a experiência do prazer se relaciona com essa tríplice divisão temporal já está presente no Filebo (34b e 36b) de Platão.

\footnotetext{
${ }^{19}$ Tusculanes V 33,96.
} 
Também em Sobre os Sonhos, Fílon observa que certos homens restringem

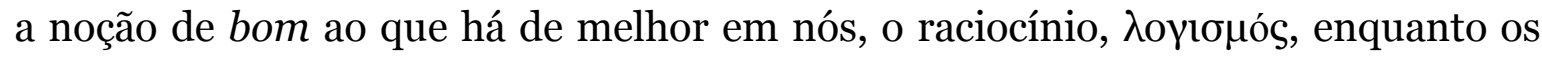
dados ao prazer a estendem à alma como um todo, ao corpo e às coisas externas ao corpo (Somn. 2.9). Essa variação dos limites da definição do bom lembra os candidatos a bom arrolados no Eutidemo (279) de Platão, mas também, e de modo ainda mais próximo, se relaciona com a formulação de Aristóteles em E.N. I 8. Ainda, ao distinguir os que admitem o bom sem mistura ( $\alpha \mu \nu \tilde{\eta})$ dos que praticam

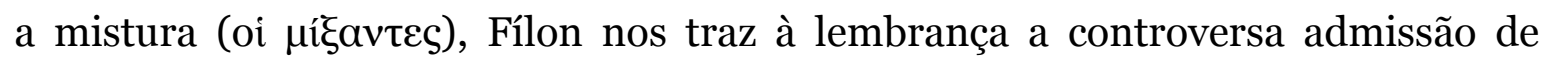
Sócrates no Filebo, que indica a necessidade de "buscar o bom não na vida sem

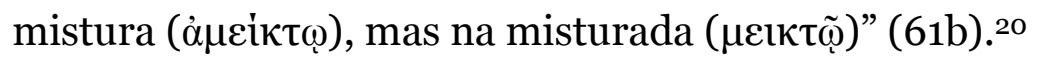

Se, aparentemente mais que Sócrates, Fílon resiste à mistura, assim como o estoico Sêneca (Vita Beata 15.2), concordará, por outro lado, com o ateniense quanto à estrutura da alma, algo relevante para a dinâmica do prazer. Ambos a entendem como composta de diferentes partes, das quais uma é racional. Essa, segundo o alexandrino, é afrontada não somente pelo corpo, mas também pelas partes irracionais da própria alma (Somn. 2.151). Sócrates também se refere a um embate entre partes da alma (Resp. 439d), que introduz a noção da tripartição da

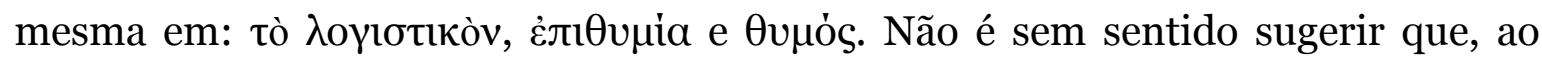

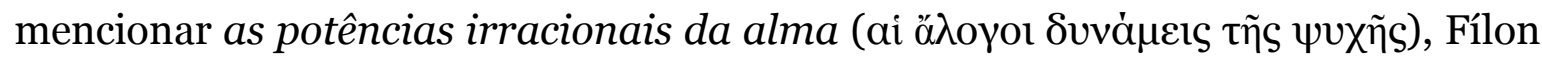
estivesse se referindo a (algo como) essas duas partes da alma que, segundo

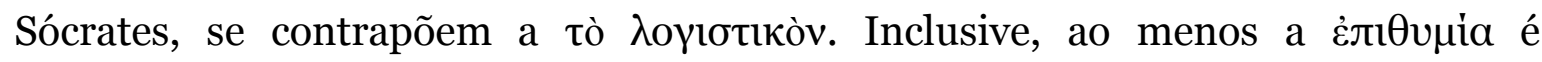
chamada por Platão de à $\lambda$ óyıotóv e caracterizada como "companheira de certas repleções e prazeres" (439d).

Nisso que aproxima o alexandrino do pensamento de Platão, Boulluec encontra um ponto de diferenciação entre Fílon e os estoicos, uma vez que estes defendiam a unicidade da alma (BOULLUEC, 1998, p. 133). Essa diferença para

\footnotetext{
${ }^{20}$ Há quem sustente que Sócrates aceita a mistura por entender que a presença do prazer é algo inevitável (FREDE, 1985; EVANS, 2007), enquanto também há uma forte tendência a se reconhecer que o filósofo não pretende mesmo repudiar, mas sim incorporar o prazer (CARONE, 2000).
} 
com os estoicos ${ }^{21}$ se faz perceptível justamente por causa de outras tantas semelhanças que Fílon exibe com relação ao estoicismo no que diz respeito ao prazer. A concepção estoica da divisão quádrupla das paixões ( $\pi \dot{\theta} \theta \eta$ ), que seria corrente desde Zenão ( $S V T$ 211), se reflete na argumentação de Fílon, como em Leg. 2.7-8, podendo inclusive ser aproveitada para a interpretação alegórica de um episódio do Pentateuco, como quando um cavalo que figura no texto bíblico (Gn 49,17) é associado às paixões por ter quatro patas (Leg. 2.99), ou na associação alegórica das quatro paixões aos quatrocentos anos de servidão prenunciados a Abraão (Gn 15,13). Mas convém ressaltar que apesar de ser apenas um dos quatro tipos de paixões, o prazer tem certa proeminência, e pode ser visto como a origem de todos os demais (Leg. 3.113).

Além de alguma concordância estrutural no que diz respeito ao prazer, os estoicos podem guardar com Fílon também alguma semelhança menos fundamental, mas também significativa, na forma da exposição do pensamento sobre o prazer. Leiam-se as seguintes palavras do exegeta:

Então, os que dizem ser "bom" somente o que é nobre, preservando sua natureza sem mistura ( $(\dot{\alpha} \mu \imath \gamma \tilde{\eta})$, restringem o termo à parte mais excelente dentre as que há em nós, o raciocínio ( $\lambda$ oүı $\sigma \mu \tilde{\omega})$. Já os que misturam a associam a três coisas: à alma, ao corpo e às coisas do exterior. Estes são

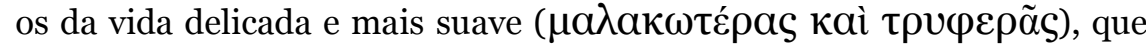
foram criados, desde os próprios cueiros, a maior parte do tempo em

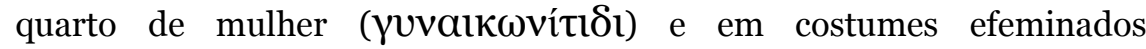

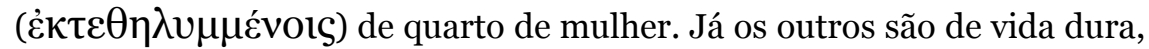
que foram criados junto a homens quando crianças, e sendo eles mesmos homens com relação ao pensamento, sendo receptivos para com o conveniente antes que para com o prazeroso ( $\dot{\eta} \delta$ ćos), e lançando mão de nutrição atlética com vistas à força e ao vigor, não com vistas ao prazer (i்ovív). (Somn. 2.9)

\footnotetext{
${ }^{21}$ Se bem observada, essa diferença reproduz uma discussão instalada o interior da própria escola, como reconhece Boulluec. Entre ll e I a.C., alguns filósofos estoicos, como Possidônio, passaram a adotar a noção de alma composta, e não simples. Parece ser um empréstimo da tradição platônica, semelhante ao que acontece em Fílon.
} 
Em seguida, tendo percebido a imagem que o alexandrino constrói para o homem que busca o prazer, convém ler de Sêneca:

Quem quer que tenha se aproximado da virtude, dá provas de sua natureza nobre. Quem segue o prazer (voluptatem) é visto fraco (enervis), despedaçado (fractus), alguém que abandona a masculinidade (degenerans viro) e que está a ponto de cair na infâmia (turpia) [...] (De Vita Beata 13.4).

A semelhança pela ênfase na delicadeza, fraqueza e, sobretudo, afastamento da masculinidade é notável. Faz-nos perceber que a inserção de Fílon na tradição filosófica não se revela apenas por aproximações com o pensamento passado, mas também pela proximidade que tem com a produção filosófica contemporânea, inclusive escrita em outro idioma. E essa proximidade alcança não somente, como disse, questões fundamentais, mas também formas de expressão.

Contudo, mesmo opondo-se de forma tão radical aos prazeres, Fílon pode reconhecê-lo (extraordinariamente) como componente indispensável da natureza humana (Leg. 2.822; Leg. 2.71), de tal modo que se faz presente até mesmo na forma mais austera de vida (Somn. 2.60). Assim, uma interpretação de Gn 2,19, em que os animais apresentados por Deus a Adão são lidos como as paixões

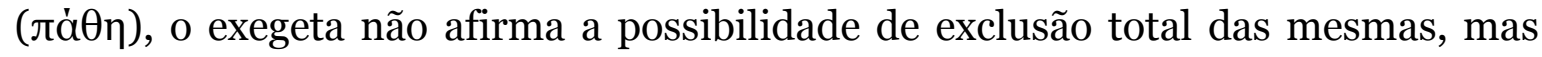
sim uma variação em sua apreciação. Enquanto o homem ruim ( $\varphi$ aṽ

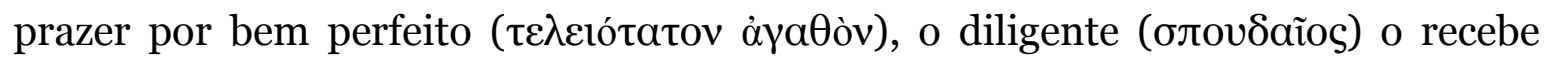

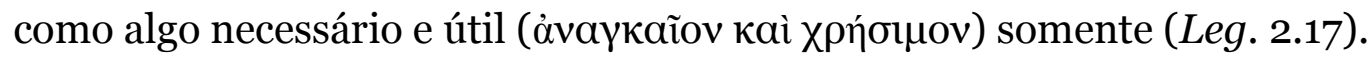

\footnotetext{
22 Trata-se de um texto difícil. A partir de uma interpretação alegórica dos animais como paixões, Fílon os apresenta como "ajudadores" do homem, tal qual Eva. Por conseguinte, descreve formas como tais paixões contribuem positivamente para a vida humana. O prazer, por exemplo, proporciona nossa multiplicação, enquanto a ira é uma arma de defesa. No prosseguimento do texto, contudo, os mesmos animais são apresentados como seres selvagens que não são propriamente ajudadores, mas inimigos. Richard Goulet sugere que o primeiro trecho, positivo com relação às paixões, é tomado por Fílon de alegoristas anteriores, e, em seguida, amenizado ou corrigido pelo alexandrino (GOULET, 1987, p. 127-129). Alain Le Boulluec discorda, e procura desfazer a contradição por uma leitura da interpretação como sendo toda de Fílon e coerente. A mudança entre a apreciação positiva e negativa das paixões se deveria a diferentes etapas. As paixões seriam proveitosas tal qual foram criadas por Deus, mas nefastas tal qual vivenciadas pelos humanos (BOULLUEC, 1998, p. 145). Apesar de entender, como Goulet, que Fílon insere frequentemente discursos alheios em sua exposição sem os anunciar, parece-me que um caminho a se pensar seria ler o prosseguimento da exposição e chegar a Leg. 2.17, que menciono a seguir. A presença das paixões parece mesmo, assim como no caso da percepção sensorial, algo necessário e útil para a vida no mundo físico (que não é a vida ideal). Nesse trecho, Fílon estaria sinalizando para um controle das paixões, como Aristóteles, e não sua supressão total (cf. WINSTON, 2008, p. 212).
} 
O alexandrino não se compromete definitivamente com uma ou outra escola. Duas perspectivas diferentes e rivais podem ser mobilizadas por ele. Estoicos e peripatéticos, apátheia e metriopátheia, diferentes perspectivas são aproveitadas em diferentes trechos. A bem da verdade, há certa clareza de que ele entende a apátheia como o ideal, mas restrita a poucos, enquanto a maioria, ele mesmo inclusive, precisaria dedicar-se à metriopátheia. ${ }^{23}$ Ainda assim, John Dillon afirma que "Fílon é bem capaz, então, de vestir um chapéu estoico ou peripatético, conforme o assunto parece demandar” (DILLON, 1997, p. 191). David Winston, por sua vez, sugere que, apesar da inconstância, o pano de fundo do pensamento de Fílon sobre o prazer está nas concepções mais tradicionais do estoicismo. Seria esperado que Fílon se aproximasse de um estoicismo platonizado, como de Possidônio, por sua frequente apropriação de elementos platônicos na discussão de outros temas, e até mesmo pelo esporádico uso de um imaginário platônico na exposição das paixões (cf. WINSTON, 2008, p. 205). Não obstante, "sua própria afinidade com muito do que estava na visão do estoicismo antigo o constrangia a usar esse novo paradigma de modo seletivo" (WINSTON, 2008, p. 202). De fato, percebe-se uma consideração especial do alexandrino pela antiga Stoa no que diz respeito ao prazer e às paixões em geral. Entendo que isso se deve à sua estratégia, sobre a qual discuto adiante. Mesmo assim, contudo, é importante dizer que isso não significa que ele se comprometa com os antigos estoicos, mas que os utiliza conforme seu intento, podendo se afastar inclusive deles se sua atividade hermenêutica e didática o solicita. ${ }^{24}$

Entre variadas semelhanças para com diversos discursos gregos (estoicos, platônicos, peripatéticos e médio-platônicos), Fúlon marca sua peculiar diferença

\footnotetext{
${ }^{23}$ Moisés (Leg. 3.129,134) e Isaque (Det. 46) experimentam a apátheia. Aarão (Leg. 3.132) e Abraão (Abr. 257), respectivamente em oposição aos anteriores, só alcançam a metriopátheia. Moisés e Isaque são os personagens mais elevados segundo a leitura de Fílon. A apátheia é, pois, a situação ideal, enquanto a metriopátheia é adequada a quem está em processo de aperfeiçoamento. Isso fica claro pela leitura da contraposição entre Moisés e Abraão (cf. Leg. 3.129-134), ou pela contraposição entre Moisés e os homens ordinários em Leg. 2.91. A Torah é, pois, de certa forma, para os ordinários. Isso se percebe pelas interpretações que Fílon tece para a circuncisão e interdição do consumo de suínos e peixes sem escamas, antes apresentadas. Considere-se também a nota 18.

${ }^{24}$ Por exemplo, ao estudar a interpretação de Fílon para a cena da oração de Ana (1 Sm 1,10ss), Scott Mackie constata: "Em sua representação de Ana em Ebr. 143-152, contudo, Fílon toma elementos igualmente de ambas as concepções psicológicas, platônica e estoica, embora as qualifique, adapte e corrija livremente quando necessário" (MACKIE, 2014, p. 151).
} 
ao afirmar a centralidade de Deus no embate contra o prazer. Em uma referência autobiográfica, diz que muitas vezes havia ido ao deserto para dedicar-se à contemplação das coisas mais dignas, mas que se havia frustrado porque, mesmo ali, sua mente fora atacada pelas paixões. Outras vezes, mesmo estando no meio da cidade, sua mente havia sido capaz de isolar-se, porque Deus havia dispersado a multidão que envolvia seus pensamentos em seu interior. Assim, aprendeu que, para o bem ou para o mal, não importa o lugar, mas sim "Deus que movimenta e conduz a carruagem da alma para onde quer" (Leg. 2.85).

Poder-se-ia pensar que nisso que vejo diferença, haveria, pelo contrário, uma semelhança, ao menos para com Sêneca, que na Carta XLI instrui Lucílio a procurar auxílio para o progresso moral não em templos, mas no espírito santo (sacer spiritus ${ }^{25}$ ), no deus dentro de si (deus intus). Deve-se, contudo, perceber que a concepção de divindade de Fílon é absolutamente diversa. O divino a que Sêneca propõe que se recorra é a própria razão humana. James Ware percebeu e demonstrou a mesma diferença entre as concepções de Paulo e de Sêneca (WARE, 2008, p. 272). Não é surpreendente que a posição do judeu Fílon se assemelhará no presente caso mais à do judeu Paulo, distanciando-se tanto dos estoicos, quanto dos aristotélicos e platônicos. Tanto é assim que, como o apóstolo (2 Cor. 4,7), Fílon convida seu leitor a reconhecer com humildade que, em última instância, o progresso moral depende de Deus, ainda que seja algo que também (ou melhor, primeiro) depende do ser humano. A partir de uma interpretação alegórica do episódio em que Deus destrói os egípcios no mar após a passagem dos hebreus (Ex 14), o alexandrino afirma que o ser humano deve se calar com reverência quando a divindade aniquila o prazer e as outras paixões (Somn. 2.266-267; cf. Leg. 2.101102). Ademais, ele afirma categoricamente que não está naturalmente no ser humano a medida das coisas (nem mesmo no homem bom, como sugere E.N. 1176a), mas no Deus único e transcendente:

${ }^{25}$ Não está implicada no termo "santo" a noção de pureza, mas sim de separação e distanciamento do convívio ordinário. 
Verdadeira e justa medida é considerar que o único Deus justo é medida e padrão de peso de tudo, e delimita a natureza do universo com números, limites e fronteiras. Por outro lado, medida injusta e falsa é julgar que estas coisas acontecem segundo a mente humana. (Somn. 2.194).

Essa dinâmica de semelhanças e diferenças pontuais confirma o fato de que Fílon elabora de modo explícito e atento uma articulação entre a Torah e a filosofia no que diz respeito ao prazer. Não obstante, para compreender melhor sua agenda, de modo a tecer uma hipótese que vá além de tal constatação, identificando sua motivação, tão importante quanto a relação positiva de Fílon para com certas escolas filosóficas gregas, é a consideração de sua relação negativa com o pensamento hedonista grego. Sua crítica aos defensores do prazer é frequente, e seria possível pensar que os cirenaicos ${ }^{26}$, com sua radical defesa de um hedonismo linear, seriam seus mais diretos adversários. Não obstante, os epicuristas recebem mais atenção.

Para explicar a relação alegórica que propõe entre a serpente do Éden e o prazer, Fílon apresenta analogias visuais entre o prazer (ou o amante do prazer) e o animal. Quando menciona o fato de a serpente ter voz humana, sua resposta é direta: "É dito que a serpente emitia voz humana, porque o prazer lança mão de inúmeros defensores e lutadores em seu favor, os quais se encarregam de seu cuidado e proteção" (Opif. 160). Em seguida, exemplifica os discursos desses defensores referindo-se a ideias do epicurismo (cf. RUNIA, 2001, p. 375). Sem nomear o filósofo, acusa-o pela escolha das teses arroladas. Entre elas, está a

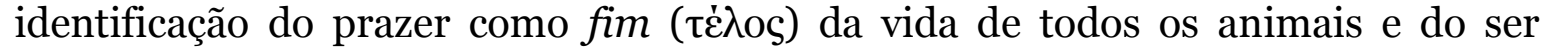
humano especialmente (Opif. 162). Essa é uma referência importante, porque Epicuro, diferente de filósofos hedonistas anteriores, não define o prazer como o

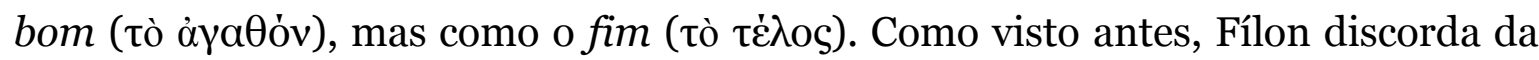
participação do prazer na definição do bom. Então, sabendo que, como ele, o hedonista Epicuro, seu adversário, também não localiza o prazer em tal âmbito, ele

\footnotetext{
${ }^{26}$ Boulluec percebe uma polêmica dirigida aos cirenaicos em Post. 79 (BOULLUEC, 1998, p. 142). Apesar da escassez de embates diretos e exclusivos com os cirenaicos, as próprias diatribes em favor da extirpação dos prazeres já lhes servem de oposição.
} 
denuncia também sua proposta. ${ }^{27}$ Em Opif. 162, ele o faz ao localizar a tese na boca da serpente. Em Conf. 144, em uma interpretação alegórica do relato da construção da Torre de Babel, Fílon identifica os construtores da torre como aqueles que promovem o politeísmo e os que afirmam ser o prazer o fim da vida ( $\tau \dot{\epsilon} \lambda$ os). Decerto, embora a primeira característica dos construtores não concorde com a cosmovisão de Epicuro, ainda que também seja acusada como impiedosa, a segunda é muito precisa.

Fílon menciona a tradição epicurista nominalmente apenas uma vez em sua obra, e o faz para acusá-la não por seu hedonismo, mas referindo-se à sua impiedade (Post. 2) ${ }^{28}$. Apesar de tal crítica nominal se dever à impiedade, sua posição favorável ao prazer é decisiva na reação do alexandrino. Ou seja, entendo que não é por sua impiedade (ou mesmo pelo materialismo subjacente a ela) que Epicuro se torna adversário de Fílon no debate sobre o prazer. ${ }^{29}$ Alguém poderia supor que a oposição do alexandrino a Epicuro poderia ser amenizada pela diferenciação que a doutrina deste estabelece entre prazer cinético e prazer estático. O fato é que Fílon conhece tal diferenciação, mas discorda de sua pertinência3o, o que fica claramente demonstrado em Leg. 3.160, quando interpreta a parte da fala de Deus dirigida à serpente (que é interpretada como significando alegoricamente o prazer em si) ao final do episódio do Éden:

Então, está muito bem que ele [Moisés] tenha acrescentado: "irás sobre o peito e sobre o ventre". Porque o prazer não é das coisas que permanecem em repouso e estabelecidas, mas das que se movem, e que são cheias de confusão. Porque, como a chama em movimento, assim a paixão, à maneira do fogo, movendo-se na alma, não a deixa permanecer em

\footnotetext{
27 O bom para Epicuro não é o prazer, mas a vida em si. O prazer, certamente, recebe destaque em seu pensamento, mas como fim, meta, té̉os da vida (DEWITT, 1954, p. 218-223).

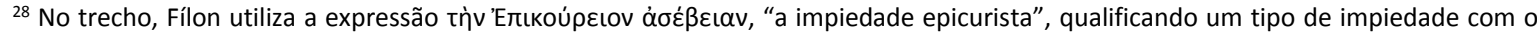

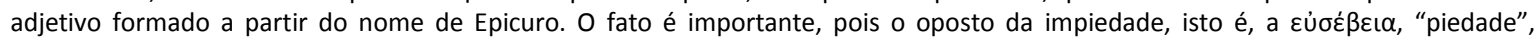
diferente do que acontece na tradição filosófica anterior, receberá destaque entre as virtudes na apresentação de Fílon (cf. STERLING, 2006). Isso mostra como também nesse aspecto Fílon se distancia de Epicuro radicalmente. Favorece também a relação que proporei entre o anti-hedonismo e o cumprimento da Torah.

${ }^{29}$ Convém notar que, no que diz respeito ao prazer, o discurso de Fílon pode se assemelhar algumas vezes ao dos cínicos, sobretudo nas diatribes, ainda que esses estejam ainda mais distantes da piedade religiosa que Epicuro. Reconheço, contudo, que, diferente do que percebo na obra do alexandrino, em Josefo (Ant. Jud. 10.277ss) e, posteriormente, na Mishnah (Sanhedrin 10.1) o conflito com Epicuro é motivado simplesmente por sua posição teológica incompatível com o monoteísmo judaico.

${ }^{30}$ Curiosamente, os cirenaicos também discordam de Epicuro nesse aspecto (Cf. WOLFSDORF, 2013, p. 179). Fílon o faz para evitar uma tentativa de amenizar o aspecto nocivo do prazer, enquanto aqueles repudiam tal ideia por não proporcionar o que consideram ser verdadeiramente prazer.
} 
repouso. De modo que [Moisés] também não concorda com aqueles que

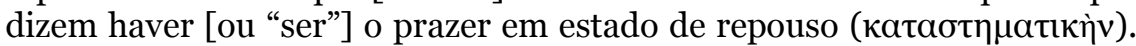
Pois o repouso é próprio da pedra, da madeira e de tudo que é sem vida, mas é alheio ao prazer, uma vez que este incita às cócegas e aos espasmos, e que, para alguns deles, é necessário não o repouso, mas um movimento intenso e impetuoso. (Leg. 3.160).

Além de repudiar esse ponto da doutrina epicúrea que a poderia tornar menos diametralmente oposta à sua proposta austera, Fílon não corroboraria a própria definição da vida (no sentido estrito de período entre nascimento e morte) como bom e do prazer (seja ele qual for) como fim. Não só a vida, na perspectiva do alexandrino, vai além do período entre nascimento e morte, como também seu fim não pode se reduzir ao prazer ou a nada que se restrinja a esse período.

Sêneca sugere que a doutrina de Epicuro não é tão nefasta quanto pensavam seus colegas, conferindo-lhe inclusive alguma honra (Vita Beata 13.1). Mas o filósofo estoico também nos dá uma possível razão adicional para a oposição decidida de Fílon. Além de reconhecer que sua postura amistosa com relação a Epicuro é uma exceção entre os estoicos, Sêneca nos faz saber da existência de pessoas que, não sendo verdadeiramente epicuristas, se valiam dos argumentos do filósofo para justificarem suas vidas dedicadas à busca dos prazeres mais brutos (Vit. Beata 12.4). Ao lançarem mão do nome, acabavam se confundindo com epicuristas, mesmo não seguindo os ensinamentos originais do grupo. É possível que o contato com tais também tenha favorecido a antipatia do alexandrino, que a meu ver transcende o âmbito da mera reflexão teórica, alcançando uma dimensão sobretudo pragmática e estratégica.

O que mais importa para meu argumento final, contudo, não é a identidade precisa dos defensores do prazer, que poderiam ser cirenaicos, epicuristas verdadeiros ou na aparência somente. Precisar exatamente o quanto Fílon valorizava suas diferenças é inviável. Seu relacionamento textual com eles não é descritivo, mas estratégico e combativo. 
Ele reconhece certa urgência e especial relevância nessa oposição que faz, como demonstra a conclusão de Sobre os Sonhos 2:

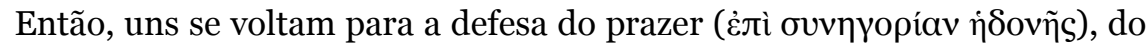
desejo e de todo impulso excessivo, fortificando uma paixão irracional contra o raciocínio regente. <Já os outros>, ao se descobrirem, se engajam em disputas cheias de rivalidades, com a esperança de mutilar a

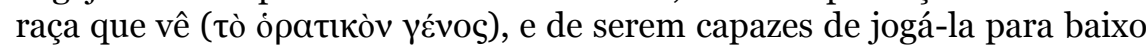
em um precipício e fenda, dos quais já não haveria como sair. Alguns ainda, se mostraram opositores não somente da virtude humana, mas também da divina. Eles se dirigiram a tal tipo de insensatez! Então, o líder da confraria dos amantes da paixão é descrito como o rei do país egípcio, o Faraó. Pois é dito ao profeta: "Eis que ele mesmo sai para a água, e estarás de pé a encontrá-lo à margem do rio" $($ Ex 7,15$)$ Pois daquele é próprio sempre lançar-se sobre o curso e a inundação da paixão irracional. Mas do sábio [é próprio] ir ao encontro desse vasto fluxo -

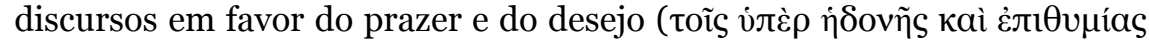

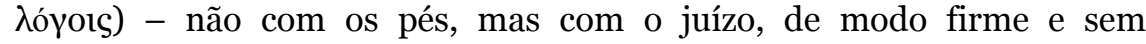
inclinação, sobre a margem do rio, isto é, sobre a boca e a língua, os quais são instrumentos do discurso. Pois, ao caminhar solidamente sobre eles, poderá reverter e abater os argumentos que advogam pela paixão. (Somn. 2.276-278).

Há no trecho uma convergência incômoda entre a querela contra o prazer e aquela em defesa da "raça que vê", que é referência a Israel.31 Isso é possibilitado pela leitura alegórica que Fílon faz do Exxodo, e que está explícita na referência ao Faraó como líder dos amantes da paixão. No sentido literal, o Faraó pode estar distante dos pensadores mais antigos ou contemporâneos de Fílon que advogavam em prol do prazer, assim como Israel é um povo monoteísta sui generis simplesmente, mas a hermenêutica filoniana é capaz de encontrar conexões a partir de um sentido menos restrito do texto bíblico. Por meio da função atualizadora da hermenêutica, o enfrentamento entre os antigos hebreus e o Faraó tal como é lido no livro do Êxodo serve como veículo de comunicação a respeito do enfrentamento continuamente possível entre os que defendem a pertinência de uma vida em busca dos prazeres e os que se opõem a eles. Trata-se de uma significativa referência meta-discursiva a respeito do embate com os "advogados do prazer”. O sábio não só resiste ao prazer, mas também se opõe aos discursos em seu favor.

\footnotetext{
${ }^{31}$ Sobre essa interpretação do nome Israel, cf. BIRNBAUM, 1996, p. 70-72.
} 


\section{Conclusão}

O prazer passa a ser tratado como problema no âmbito do judaísmo a partir de um relacionamento com o pensamento grego. Antes do encontro com a filosofia helênica, os textos do arquivo judaico não se detêm nesse tema. Além disso, ficou demonstrado que essa aproximação entre a Torah e o problema do prazer, que se estabelece como uma oposição, se realiza de modo mais complexo na obra de Fílon de Alexandria, ainda que haja paralelos em 4 Macabeus. Essa especificidade se dá justamente pela intensidade com que o exegeta alexandrino trata o tema e pela sofisticação de sua leitura (sobretudo pelo método alegórico), capaz de encontrar o problema do prazer na Torah em si, e não simplesmente trazer a Torah para uma reflexão que lhe parecia alheia.

A constatação solicita uma explicação. Fílon se apropria de discursos contrários ao prazer simplesmente para se aproximar de pensadores contemporâneos? Defende esses discursos por ver nisso uma oportunidade de divulgar a pertinência da Lei mosaica? Embora essas saídas sejam plausíveis, a ênfase com que o alexandrino se opõe não somente ao prazer em si, mas também aos discursos em favor do prazer, parece indicar que sua reação é própria de um educador judeu, e não de um apologista simplesmente. Ou seja, ele parece estar preocupado com a efetividade do Discurso Sagrado na existência da comunidade judaica, e percebe outro discurso, aquele que exalta o prazer como bem em si ou meta de vida, como um rival com potencial destrutivo. Ora, se parte de sua comunidade se convencesse da pertinência da busca do prazer como ideal para a vida, a submissão à Torah poderia perder sua preeminência. O afrouxamento na observância da Torah lhe parece tão nefasto que se opõe de modo veemente até mesmo a judeus alegoristas extremos, que teriam deixado de preocupar-se com o cumprimento literal dos mandamentos (Mig. 89-90)32. Um discurso helênico que era persuasivo e agradável aos muitos, e que, por outro caminho, poderia resultar

\footnotetext{
${ }^{32}$ Cf. Hay, 1997.
} 
em semelhante inobservância da Torah, também mereceria proporcional reação e oposição. À semelhança do que entrevejo nos versos iniciais do Salmo 1, Fílon parece suspeitar que a valorização dos prazeres comuns se opõe à submissão à

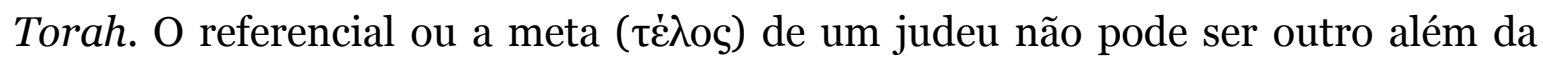
Torah, nem o bem absoluto ser a própria vida, já que pela Torah e pela devoção deve estar disposto a entregá-la (cf. Legat. 234-235).

Essa hipótese condiz com a definição do mais provável público leitor do alexandrino, que seria composto por judeus de língua grega, e não filósofos romanos ou gregos. Ele escreve como um professor de sua comunidade. Se seu discurso por vezes soa propagandístico ou apologético, é mais provável que se trate de uma apologia interna, destinada ao fortalecimento do próprio grupo e de sua autoestima em relação ao entorno (e não à persuasão dos de fora para uma possível adesão). 33

Proponho, pois, que se entenda que é em Fílon que a Torah se encontra definitivamente com o tema do prazer, já que ela mesma, em seu próprio texto narrativo e legislativo, passa a se erigir contra o hedonismo. Ademais, entendo que esse encontro é motivado pelo ímpeto de preservação da pertinência e implementação da própria Torah no cotidiano da comunidade judaica de língua grega. Os vários discursos filosóficos gregos aproveitados nesse embate são utilizados por servirem a esse fim, e não são os reais motivadores do antihedonismo da Torah como lida por Fílon.

${ }^{33} \mathrm{O}$ que proponho é semelhante ao que Tcherikover propõe com relação à Carta de Aristeas (TCHERIKOVER, 1958, p. 84). Cf. HENGEL, 1974, p. 69-70. 


\section{REFERÊNCIAS}

ANDERSON, Gary. The Garden of Eden and sexuality in early Judaism. In: EILBERGSCHWARTZ, H. People of the body: Jews and Judaism from an embodied perspective. Albany: State University of New York Press, 1992. p. 47-68.

AUNE, D. Mastery of passions: Philo, 4 Maccabees and Early Christianity. In: HELLEMAN, W. Hellenization revisited: shaping a Christian response within the Greco-Roman World. Lanham: University Press of America, 1994. p. 125-158.

Bíblia de Jerusalém. Nova edição, revista e ampliada. São Paulo: Paulus, 2002.

Biblia Hebraica Stuttgartensia. Ediderunt K. Elliger et W. Rudolph. Editio quinta emendata opera A. Schenker. Stuttgart: Deutsche Bibelgesellschaft, 1997.

BIRNBAUM, E. The place of Judaism in Philo's thought: Israel, Jews, and Proselytes. Atlanta: Scholars Press, 1996.

BOULLUEC, Alain le. La place des concepts philosophiques dans la réflexion de Philon sur le plaisir. In: LÉVY, Carlos. Philon d'Alexandrie et le langage de la philosophie. Turnhout: Brepols, 1998. p. 129-152.

CARONE, Gabriela Roxana. Hedonism and the pleasureless life in Plato's Philebus. Phronesis, Leiden, v. 45, n. 4, p. 257-283, 2000.

COHEN, S. J. D. The beauty of Flora and the beauty of Sarai. In: COHEN, S. J. D. The significance of Yavneh and other essays in Jewish Hellenism. Tubingen: Mohr Siebeck, 2010, p. 3-14.

DESILVA, D. A. 4 Maccabees. Sheffield: Sheffield Academic Press, 1998.

DEWITT, N. W. Epicurus and his philosophy. Minneapolis: University of Minnesota Press, 1954.

DILLON, J. The pleasures and Perils of Soul-Gardening. The Studia Philonica Annual. Atlanta: Scholars Press, v. 9, p. 190-197, 1997.

EVANS, Matthew. Plato's rejection of thoughtless and pleasureless lives. Phronesis, Leiden, v. 52, n. 4, p. 337-363, 2007.

FREDE, Dorothea. Rumpelstiltskin's pleasures: true and false pleasures in Plato's Philebus. Phronesis, Leiden, v. 30, n. 2, p. 151-180, 1985. 
GOULET, R. La philosophie de Moïse: essai de reconstitution d'un commentaire philosophique préphilonien du pentateuque. Paris: Libraire Philosophique J. Vrin, 1987.

HADAS, M. Letter of Aristeas: Aristeas to Philocrates. Eugene: Wipf and Stock Publishers, 2007.

HAY, D. Putting extremism in context: the case of Philo, De Migratione 89-93. The Studia Philonica Annual. Atlanta: Scholars Press, 1997. p. 126-142. v. 9

HENGEL, M. Judaism and Hellenism. London: SCM Press, 1974. v. 2.

HONIGMAN, S. The narrative function of the King and the library in the Letter of Aristeas. In: RAJAK, T. et al. Jewish perspectives on Hellenistic rulers. Berkley: University of California Press, 2007. p. 128-146.

HONIGMAN, S. La descriptionde Jérusalem et de la Judée dans la Lettre d'Aristée. Athenaeum, Ohio, v. 1, n. 92, p. 73-101, 2004.

JOSEPHUS. Jewish Antiquities, volume IV. Books 9-11. With translation of Ralph Marcus. Cambridge, MA: Harvard University Press, 1937.

MACKIE, S. The passion of Eve and the ecstasy of Hannah: sense perception, passion, mysticism, and misogyny in Philo of Alexandria, De ebrietate 143-152. Journal of Biblical Literature, [s.1], v. 133, n. 1, p. 141-163, 2014.

MARTENS, J. W. One God, one law: Philo of Alexandria on the mosaic and GrecoRoman Law. Leiden: Brill, 2003.

Mishnah - Sanherin 10. In: The Mishnah: a new integrated translation and commentary. Disponível em <http://www.emishnah.com/PDFs/Sanhedrin\%2010.pdf > . Acessado em 28 de julho de 2015 .

NAJMAN, I. A written copy of the law of nature: an unthinkable paradox? In: Studia Philonica Annual. Atlanta: Scholars Press, 2003. p. 54-63. v. 15.

NIKIPROWETZKY, V. Le commentaire de l'ecriture chez Philon d'Alexandrie. Paris: Universite de Lille III, 1973.

PELLETIER, A. Lettre d'Aristée à Philocrate. Introduction, texte critique, traduction et notes, index complet des mots grecs. Paris: Cerf, 1962.

PHILO OF ALEXANDRIA. Philo in ten volumes (and Two Supplementary Volumes). COLSON, F.H., WHITAKER, G.H. (trad.). London:Heinemann; Cambridge, MA: Harvard University Press, 1929-1962.

RUNIA, D. On the creation of the cosmos according to Moses: introduction, translation and commentary. Leiden: Brill, 2001. 
SENECA. De Vita Beata. Moral Essays. Volume II. Loeb Classical Library, 254.

Cambridge (MA): Harvard University Press, 1932.

SENECA. Espístola XVII. In: Epistles 1-65. Loeb Classical Library, 75. Cambridge (MA): Harvard University Press, 1917.

Septuaginta: id est Vetus Testamentum Graece iuxta LXX interpretes. Edidit Alfred Rahlfs. Duo volumina in uno. Stuttgart: Deutsche Bibelgesellschaft, 1979.

STERLING, G. The queen of the virtues: Piety in Philo of Alexandria. In: The Studia Philonica Annual, n. 18. Atlanta: SBL, 2006. p. 103-123.

SVEBAKKEN, H. Philo of Alexandria's exposition of the tenth commandment. 2009. 296f. Tese (Doutorado em Filosofia/ Programa em Teologia) - Loyola University Chicago, Chicago.

TCHERIKOVER, A. The ideology of the Letter of Aristeas. The Harvard Theological Review, Cambridge (MA), v. 51, n. 2, p. 59-85, 1958.

The Greek New Testament. Fourth Revised Edition Edited by Barbara Aland et al. Stuttgart: Deutsche Bibelgesellschaft, 2000.

WARE, J. Moral progress and divine power in Seneca and Paul. In: FITZGERALD, J. T. (ed.). Passions and moral progress in Greco-Roman thought. New York: Routledge, 2008. p. 267-283.

WENHAM, Gordon J. Psalms as Torah: reading biblical song ethically. Grand Rapids: Baker Academic, 2012.

WINSTON, D. Philo of Alexandria on the rational and irrational emotions. In: FITZGERALD, J. T. (ed.). Passions and moral progress in Greco-Roman thought. New York: Routledge, 2008. p. 201-220.

WOLFSDORF, D. Pleasure in ancient Greek philosophy. Cambridge: Cambridge University Press, 2013. 